\title{
NOTES
}

\section{INSURANCE ASPECTS OF PARTS AND SERVICE CONTRACTS: PROBLEMS FACING THE TELEVISION INDUSTRY}

The following press release recently appeared in a trade journal:

"Instances have been brought to the attention of the New Hampshire Insurance Department which indicate that certain concerns which distribute appliances, deep freezers, television sets and air conditioning units and which offer service contracts in connection with such goods are in fact engaged in the sale of insurance without complying with the insurance licensing laws of the state. Any contract made by service concerns which agrees to replace certain parts upon the happening of a contingency can be construed as a contract of insurance. The assumption of a hazard or risk in such a contract involves the elements of insurance.

"Properly worded warranty agreements given by the vendor at the time of sale and guarantees given by the manufacturer are not insurance, but some service contracts even though they may be labelled contracts of warranty or guaranty do include the elements of insurance. An illustration in the television field is those service contracts issued by independent service companies which agree to replace the tubes in a set on the happening of a contingency. If not properly licensed and supervised, the action of these service companies can and in some cases does result in a fleecing of the public. Such concerns are warned that the issuance of such contracts without being licensed is illegal and the public is advised to exercise caution in accepting service contracts." 1

This release illustrates the problems currently facing the profession because of the recent innovation into the commercial world of the service contract. This Note will discuss the questions raised for the lawyer, the courts, and the state insurance commissioners by this new selling device, ${ }^{2}$ using the television service contract as an example. ${ }^{3}$

1. Retailing Daily, July 31, 1952.

2. It has been used extensively only since 1938 .

3. The main terms of a typical contract are: "X Co. will service and maintain the $\mathrm{X}$ Co. television receiver and antenna to which this contract relates, in normal working order, during the term of this contract, provided that such service and maintenance are necessitated by normal usage as determined by $\mathrm{X}$ Co. If materials, parts and tubes fail to give satisfactory performance in normal usage, genuine factory replacements will be furnished during this term." These contracts generally run for one year and are subject to renewal. 
Warranties for many years have played an important part in the merchandising field, but they have not proven wholly satisfactory to either the seller or the consumer. ${ }^{4}$ The seller usually faces a customer who insists that the damage to or the inefficient running of the product is due to a material defect for which the manufacturer is responsible. If the warranty has expired, or the damage may be attributable to the customer's abuse of the product, ill-will instead of good-will results. Conversely, the customer generally finds that the waranty is f.o.b. factory, thereby requiring him or a paid technician to extract the defective part and ship it, at his own expense, to the factory. There his claim is seldom handled promptly or properly. If litigation develops the customer finds himself less efficiently represented than his corporate vendor. In addition, the present day manufacturer and customer are engaged in selling and buying appliances which are highly technical in construction. The maintenance of these appliances requires skilled service men who are not readily available. ${ }^{5}$ Since this is especially true when a new product appears on the market, its manufacturer is met with substantial sales resistance. ${ }^{6}$ Because of these motivating factors, manufacturers, dealers and independent service companies have been offering, at an additional price, a service contract to supplement the traditional ninety day warranty. The service contract may cover the replacement of parts for a period of time in addition to the warranty, the cost of labor to replace the parts, or both. ${ }^{7}$

\section{Problems of Draftsmanship}

The biggest problem for the draftsman is how to make sure that his contract will not be classified as an "insurance contract." If this is inadvertently created, the seller would have to incorporate as an insurance company and thereby subject himself to the elaborate regulations, including a large paid-in capital ${ }^{8}$ and unearned premium reserves, which the various state insurance statutes and commissioners impose. A failure to incorporate in compliance with these statutes would subject the person or corporation to quo warranto proceedings at the will of his competitors. ${ }^{9}$ A conviction would result in large criminal penalties. ${ }^{10}$

4. See 11 Advertising Age 8 (July 18, 1938).

5. See How TV Racketeers Gyp You, 60 Reader's Digest 103, 104 (June, 1952), where it is estimated that it costs $\$ 1500$ to train a competent television repairman, and $\$ 1800$ to equip a service organization.

6. Mr. Herbert Brum, Assistant-General Attorney of Radio Corporation of America (RCA Victor Division) stated in an interview (Sept. 20, 1952) that insuring the public's confidence in this new invention was a primary factor in the company's decision to set up television service facilities on a national basis.

7. An evil has occurred when a dealer or service man sells only a contract to replace parts for a nominal sum and then charges exorbitant fees for his labor.

8. E.g., NEB. REv. STAT. $\$ 44.214$ (1943) ( $\$ 50,000$ paid in capital); N.Y. INS. LAw \$311 ( $\$ 100,000$ paid in capital); MICH. Srat. ANN. \$24.213 (Moore 1943) ( $\$ 200,000$ paid in capital).

9. See 23 MarQUETTE L. ReV. 91 (1939).

10. E.g., OHIo GEN. CODE ANN. $\$ 672$ (Page 1937) (Maximum of $\$ 1000$ fine for each offense and/or maximum of 6 months imprisonment); PA. STAT. ANN. tit. $40, \S 47$ (Purdon 1930) ( $\$ 500$ for each month or fraction thereof, in which said illegal business was transacted); MD. ANN. CoDE GEN. LAws art. 48A, §67 (Flack 1939) ( $\$ 100-\$ 1000$ fine for each offense). 
Statutory and Common Law Themes.-State insurance statutes give little help in determining what constitutes a contract of insurance since they either define insurance in broad and useless terms ${ }^{11}$ or give no definition at all. ${ }^{12}$ One of the most generally accepted definitions of insurance is that given in a Massachusetts case, ${ }^{13}$ where the court stated that a contract of insurance is an agreement by which one party, for a consideration, promises to make a certain payment of money upon the destruction of or injury to something in which the other party has an interest. Neither the amounts of payment by the assured nor the modes of ascertaining or securing the payment of the sum to be paid by the insurer affect the question of whether the agreement between them is a contract of insurance. The only requisites to such a contract are the payment of consideration by the one and the promise by the other to pay the amount of the insurance upon the happening of injury to the subject, caused by a contingency contemplated in the contract. ${ }^{14}$ This definition, like most statutory definitions, is broad enough to include almost any contract in which one party assumes another's risk. One writer has listed five elements for the existence of a contract of insurance. They are: "(a) The insured possesses an interest of some kind susceptible of pecuniary estimation, known as an insurable interest. (b) The insured is subject to a risk of loss through the destruction or impairment of that interest by the happening of designated perils. (c) The insurer assumes that risk of loss. (d) Such assumption is part of a general scheme to distribute actual losses among a large group of persons bearing somewhat similar risks. (e) As consideration for the insurer's promise, the insured makes a ratable contribution, called a premium, to a general insurance fund." 15 He explains that a warranty contains the first three, but a contract of insurance contains all five. Although this is undoubtedly correct, (d) and (e) contain the words "general scheme" and a "general insurance fund" which are of as little help as the broad definitions found in an insurance statute. Does the nature of the contract depend upon whether the parties intended to engage in the insurance business; upon whether a sum of money is separated from the corporate assets and labeled insurance fund; upon whether the contract is sold separately from the product; upon the length of time the contract is to be effective; upon whether the indemnity is to be made in money rather than services; upon the nature of the for-

11. E.g., Kx. REv. STAт. $\$ 304.002$ (Supp. 1950) ("Insurance is a contract whereby one undertakes to indemnify another or pay a specified amount upon determinable contingencies.") ; MD. ANN. CoDE GEN. LAws art. 48A, \&1 (Flack 1939) ("Insurance business, or business of insurance means and embraces . . . an obligation or undertaking of any kind or nature whatsoever insuring against or undertaking to indemnify any person for loss resulting from any contingency, hazard or casualty.").

12. E.g., Ill., Pa., and Mich.

13. Commonwealth v. Wetherbee, 105 Mass. 149 (1870).

14. This was codified in Mass. GEN. Laws c. $175, \$ 2$ which states: "A contract of insurance is an agreement by which one party for a consideration promises to pay money or its equivalent, or to do an act valuable to the insured, upon the destruction, loss or injury of something in which the other party has an interest."

15. Vance, Insurance 1 (3d ed. 1951). 
tuitous contingencies for which the replacement of parts or services are to be rendered; or upon whether an independent service man, a dealer or a manufacturer makes the contract? These questions remain unanswered by the definitions of insurance. Traditionally the lawyer would look to the courts for guidance in their answers, but the courts have been as indefinite in their "definitions" of insurance as the statutes. ${ }^{16}$

Judicial Undertones.-A typical service contract indemnifies against both replacement of parts and incidental labor costs. Each of these raises different problems which will be discussed separately.

(a) Scope of a Contract of Warranty of Parts.-This problem may again be subdivided into the different considerations involved when warranties are offered by (1) a manufacturer or dealer, or (2) an independent service man. No cases have been decided involving an independent service man giving only a warranty on another's goods, but his inability to do so without engaging in the insurance business will become apparent from the following decisions.

The earliest case of a mamufacturer attempting to offer something more than a warranty of quality is Cole Brothers \& Hart v. Haven. ${ }^{17}$ There, a lightning-rod dealer, in order to promote sales of that new product, ${ }^{18}$ promised to pay all damages up to $\$ 500$ caused by lightning to the structure upon which the rods were erected. The Iowa court held, in a suit by the manufacturer against a debtor-purchaser, that the contract was not one of insurance stating, "One may sell goods and agree that the purchaser will receive certain benefits or advantages. Such a contract would be a guaranty or warranty and not a contract of insurance." 19 Here the court looked to the intent of the parties and found that the main purpose of the contract was the sale of lightning-rods. The benefit to the purchaser of having the manufacturer pay for any damage caused by lightning was declared to be incidental to the inducement to purchase.

This "contingent incidental benefit test" was applied in later cases in other jurisdictions, ${ }^{20}$ but a counteracting test was also being developed. In Ollendorf Watch Co. v. Pink, ${ }^{21}$ a manufacturer of watches issued, with each watch sold, a certificate under which he promised to replace the watch

16. Most of the case law has involved enterprising businessmen attempting to sell a new product.

17. 7 N.W. 383 (Iowa 1880).

18. Lightning-rods were first used to protect buildings in 1876. 14 ENcycloPAEDIA BRITANNICA 116 (14th ed. 1929).

19. Cole v. Haven, 7 N.W. 383, 384 (Iowa 1880).

20. Evans \& Tate v. Premier Refining Co., 31 Ga. App. 303, 120 S.E. 553 (1923) (agreement by seller of oil to replace gears in automobiles if they wear out while using said oil held to be a contract of warranty); Lamson Consolidated Store-Service Co. v. Conyngham, 11 Misc. 428, 32 N.Y. Supp. 129 (1898) (agreement to keep cash register in repair from ordinary wear and tear for 2 years free of charge held to be a contract of warranty). In both cases a relatively new product was involved, automobiles becoming popular in early twenties and cash registers being invented in 1879 .

21. 279 N.Y. 32, 17 N.E.2d 676 (1938). 
with a new one of like quality provided the first should be lost in the United States or Canada through burglary or robbery within one year of purchase. The lower court, in construing the Massachusetts common law definition of insurance, ${ }^{22}$ applied the "contingent incidental benefit test" and refused to interfere with a "modern businessman's new venture." ${ }^{23}$ The Court of Appeals of New York reversed, stating that since theft was not an occurrence within the control of the party promising the indemnity it could not be construed as a contract of warranty. By this decision the court limited the scope of the warranty to quality and title, those being the only things within the control of the promisor.

In the same year an Ohio case extended the control test. In State ex rel. Duffy v. Western Auto Supply Co. ${ }^{24}$ a seller of automobile tires guaranteed them for a given period against "blowouts, cuts, bruises, rim cuts, underinflation, wheels out of alignment, faulty brakes or other road hazards (except fire or theft)." This contract was held to be one "substantially amounting to insurance," therefore requiring compliance with the insurance statutes of the state of Ohio. This decision has been criticised as an unnecessary interference with a businessman's selling device. ${ }^{25}$ Certainly it seems difficult to hold that a manufacturer who warrants his tires to be so well constructed that nothing can harm them is engaged in the insurance business.

Three years later the same court, in State ex rel. Herbert v. Standard Oil Co., ${ }^{26}$ retreated from its former position. Here a manufacturer of tires assured repairs or replacements of its tires if they failed ". . . to give the purchaser satisfactory service under the usual conditions of wear and tear. . . ." The court held that the tire manufacturer was not engaging in the insurance business. This case can be distinguished from the Duffy case, in that there the loss insured against resulted from risks which included those unrelated to defects in the article itself, while here the loss insured against resulted from faulty construction of the tires. However, several aspects of the case are worthy of note. (1) Evidence that the manufacturer had replaced tires cut from curbs and broken bottles was excluded. This would have shown what meaning was given by the parties to the words "ustral conditions of wear and tear."

(2) The court suggested the enactment of remedial legislation to deal with the problem directly. (3) The court stated that the insurance laws were not intended to apply to purely commercial transactions in the merchandizing field, thereby leaning towards the "contingent incidental benefit" theory. (4) The court suggested that the rule of the Duffy case should not be extended.

From these cases one can make certain generalizations. The lawyer should advise his manufacturer-client to restrict his assumption of risk to

22. The New York statute contained no definition of insurance; hence the court turned to the well-developed Massachusetts law. See note 14 supra.

23. The lower court felt it was merely a new selling device.

24. 134 Ohio St. 163, 16 N.E.2d 256 (1938).

25. 48 Y ALE L.J. 117 (1938).

26. 138 Ohio St. 376, 35 N.E.2d 437 (1941). 
those deficiencies which arise from material defécts caused by poor workmanship. The use of the words "to replace parts which become defective through the normal use of the product" is advisable. No obligation should be assumed for consequential damage ${ }^{27}$ or for normal wear. If the coverage is extended to all contingencies except fire, theft, lightning and the like, the fate of the contract will be in the court's discretion. A commercially wise court would apply the "contingent incidental benefit" theory, but there is no sufficient trend in any jurisdiction upon which a lawyer can rely. If extended coverage is desired, the contract should be so worded that it appears that the product is made to withstand all damage from the specified contingencies, and that all loss is the result of poor workmanship. A contract covering all contingencies including acts of God will most certainly be held a contract of insurance.

The length of time the contract is to run should be limited to the period of time in which defects caused by faulty construction normally appear. A renewal of a warranty against defects caused by faulty workmanship may also bring into play the "control test," since the court may declare that there is no better indication of the proper period of time a warranty may run than that period put upon it by the maker's or seller's original assumption of responsibility at the time of and as part of the original sale. ${ }^{28}$ A further defect inherent in a renewal contract is that it is not entered into at the time of the original sale, and thus the "contigent incidental benefit test" may not be used to militate against the result of insurance. ${ }^{29}$

If possible, the price of the warranty should be included in the list price of every article sold..$^{30}$ If for business reasons it must be made optional and the price stated separately, the client should charge a flat rate. To avert the possibility that assumption of the risk will be held to be the consideration for the premium, it would be advisable to word the consideration in the form of a waiver of the disclaimer for material defects which occur after the traditional warranty period. However, the separate pricing factor logically should have little bearing on the nature of the contract, since even without separate pricing all warranties are paid for by the customer through their inclusion in the retail price of the product.

Since a dealer exercises choice as to the product he will sell, his assumption of responsibility for its quality and efficiency is as great as that of a manufacturer. Through this ability to select, the dealer is deemed to have control over the defects which arise from poor workmanship. ${ }^{31}$ There-

27. Although the law may impose liability for consequential damage upon the seller, liability is still extended by the use of this phrase since the buyer does not have to prove negligence.

28. See REP. ATTY GEN. 153 (N.Y. 1949).

29. Since the "contingent incidental benefit" theory was developed to allow a seller to make his product more attractive, it can be argued that a renewal feature in a contract sold with the product also accomplishes this and the test should apply.

30. See Commonwealth ex rel. Hensel v. Provident Bicycle Assoc., $178 \mathrm{~Pa}$. 636, 36 Atl. 197 (1897).

31. Although this is not true in practice, this doctrine has become well engrained in sales law. See Jones v. Just, L.R. 3 Q.B. 197 (1868); Bonenberger v. Pittsburgh Mercantile Co., 345 Pa. 559, 28 A.2d 913 (1942); 1 WIILISTON, Sales $\$ 233$ (2d ed. 1948). 
fore the same type of contract may be drafted for the dealer-client as for the manufacturer-client. 32

Finally, it can be inferred from the above cases that an independent service man, having no relation to the selling of the product for which he contracts to replace parts upon a certain contingency, unrelated to any work he may have previously performed upon the product, would be engaged in the insurance business. ${ }^{32 a}$ The contract would not meet the control test which the courts have frequently applied. On the other hand, if he warrants parts which he himself has replaced, his position is analogous to that of a dealer and the same considerations should apply. If he warrants his own services, he is analogous to a manufacturer. Whether he may contract to replace parts that wear out due to his lack of care or faulty repair of the product will be discussed in the following sub-section.

(b) Scope of a Contract for Future Services. -The problem becomes more complicated when the client wishes to contract not only to replace parts but also to keep the article in working condition and repair it when needed. A man may clearly bind himself to perform services in the future; however, an insurance problem arises if the rendering of those services is dependent upon a fortuitous event and results in shifting of a risk. ${ }^{33}$

A manufacturer or dealer who promises to furnish labor to replace a part which becomes defective due to faulty workmanship within a period of time in which the fault would normally appear is not engaging in the insurance business, since the contingency was within his control; neither is an independent service man who limits the coverage of the contract for prepaid future services to machines he has previously repaired and to contingencies attributable to such prior repair work. When a manufacturer or dealer extends the coverage to include contingencies beyond his control, or when an independent service man contracts to do future work for a prepaid sum, such work to be rendered on the happening of a specified contingency unrelated to any previous work performed by him, the courts have

32. See Rep. Atr'y GEN. 153 (N.Y. 1949).

32a. Ibid. The following analysis was stated in a communication to the UNIVERsity of PENnsylvania Law Review from Mervin R. Samuel, California Deputy Insurance Commissioner (Nov. 6, 1952), on file, Biddle Law Library, University of Pennsylvania Law School:

"This Department's approach to the problem has been on the following basis: If a television warranty is reasonably related to a guaranty of the product and the warranty is given by the manufacturer or by the dealer to a person to whom such manufacturer or dealer sells a television set, it is probably more in the nature of a guaranty than insurance and probably would not be subject to insurance laws. If, on the other hand, a person who is not a manufacturer or a dealer who has made the original sale of the television set to a customer, it is doubtful that he could properly warrant it. If he should enter into a television warranty contract, it is probable that he would be acting as an insurer."

33. The risk-shifting factor is necessary. It is illustrable by the following hypothetical cases: (1) if $X$ promised to put a new roof on Y's house if Y's son married X's daughter on the twenty-third of June, no element of risk-shifting is involved; but (2) if $X$ promised to put a new roof on $Y$ 's house any time it was damaged by storm if Y's son married $X$ 's daughter on the twenty-third of June, a risk is shifted from $Y$ to $X$. 
split on whether he is engaging in insurance business. Positing a shift in risk, the following tests have been applied:

(1) An absence of a promise to pay money as indemnity for the loss indicates that the contract is not one of insurance.-Thus in Commonwealth ex rel. Hensel v. Provident Bicycle Ass' $n^{34}$ it was determined by the court that a bicycle association which, for an agreed annual membership fee, promised to clean a member's bicycle twice a year, to repair it if damaged by accident, and to replace it if stolen, was not engaged in the insurance business. An important factor influencing the court's decision was the fact that the bicycle owners received no money upon the happening of the fortuitous event. Other courts have rejected this as a distinguishing factor even where state statutes fail to define insurance, or define it as payment by the promisor in money. ${ }^{35}$

(2) Operation in a limited area and with a somewhat limited clientele may indicate that the contract is not one of insurance.-In Moresh $v$. $O^{*} \operatorname{Regan},{ }^{36}$ the court decided that a contract in which petitioner for a stipulated sum agreed to repair store-front plate glass by tightening the bars or clamps holding it in place and to replace any such glass which was broken at any time in the future, was not a contract of insurance under the New Jersey statutes. In this case, the court took cognizance of the fact that the promisor operated in a limited area with a limited clientele, negating a need for public regulation. An opposite conclusion was reached in People $v$. Standard Plate Glass and Salvage $\mathrm{Co}^{37}$ where an agreement to inspect and putty glass during the period of the contract and to replace the glass in case it should become broken was held to be a contract of insurance in evasion of the New York insurance statutes. ${ }^{38}$

(3) Performance of the services by other than the promisor indicates that the contract is one of insurance.-Physicians Defense Co. v. Cooper ${ }^{39}$ held that an organization which agreed to provide attorneys for defense of malpractice suits against physicians was engaging in the insurance business. The court stated, "Such a contract, in our opinion, cannot be classed as a contract for personal services. The company is not itself a lawyer, and does not undertake the defense as such. What it does undertake . . . is to employ a local attorney who . . . will defend the case. . . " 40 Since the primary purpose of insurance is to gain protection rather than the work of a specific person, this distinction has some merit.

34. 178 Pa. 636, 36 At1. 197 (1897).

35. E.g., State v. Bean, 193 Minn. 113, 258 N.W. 18 (1934); National Auto Service Corp. v. State, 55 S.W.2d 209 (Tex. Civ. App. 1932).

36. 120 N.J. Eq. 534, 187 Atl. 619 (1936) (later reversed on another ground).

37. 174 App. Div. 501, 156 N.Y. Supp. 1012 (1916).

38. Accord, People v. Roschli, 275 N.Y. 26, 9 N.E.2d 763 (1937).

39. 199 Fed. 576 (9th Cir. 1912).

40. Id. at 578. Contra: Vredenburgh v. Physicians' Defense Co., 126 Ill. App. 509 (1906). 
(4) A flat rate as opposed to a graduated rate in accordance with the risk involved is an indication that the contract is not one of insurance. ${ }^{41}$

(5) Uniqueness of the service contracted for is an indication that the contract is not one of insurance. ${ }^{42}$ - This is a corollary to the test of whether the promisor performs the services himself. Uniqueness or lack of it is not conclusive as to whether the service was the thing contracted for, as distinguished from a mere intent to shift the risk, but it tends to throw light upon the intent ${ }^{43}$ of the parties.

It should be understood that none of the above tests is conclusive. As soon as a contract for future services is made contingent upon the happening of a fortuitous event, it is capable of qualifying under the broad definitions of insurance. It should be noted that in the above cases, the contracts were risk-shifting devices, and, as they were combined with other contracts of like nature, they became risk distributing devices. Therefore, if a client wishes to make his services available for a stated period of time, for a prepaid sum or even gratuitously, such services to be given on the happening of certain fortuitous events, which results in risk-shifting, a lawyer cannot guarantee that he will not be engaging in the insurance business under most state statutes. Here again, commercially wise courts have kept before them the purposes of regulation and the purpose of the contract. If they found possibility of fraud or an attempt to evade the insurance laws the contract was declared to be one of insurance. ${ }^{44}$

If a client wishes to take the chance, the following points should be considered, in addition to restricting his clientele and territory, doing the work himself, and charging a flat rate:

(1) A dealer should not charge separately for the service contract, but should include it in the price of the article if economically possible.44a Although this factor by itself is unimportant, together with the others it may have a great psychological effect on a court's decision as to whether a man is merely giving an incidental benefit to his purchasers rather then receiving money for a risk which he has assumed and distributed.

41. Commonwealth ex rel. Hensel v. Provident Bicycle Assoc., $178 \mathrm{~Pa} .636,36$ Atl. 197 (1897). This seems a tenuous ground at best since the lack of apportionment may be due to bad business practice.

42. Allin v. Motorists' Alliance, 234 Ky. 714, 29 S.W.2d 19 (1930) ; Physicians' Defense Co. v. O'Brien, 100 Minn. 490, 111 N.W. 396 (1907).

43. "Intent" as here used is not the "contractual intent" but "intent" as shown by the main purpose of the contract.

44. E.g., State ex rel. Coleman v. Wichita Mut. Burial Assoc., 73 Kan. 179, 84 Pac. 757 (1906); Renschler v. Hogan, 90 Ohio St. 363, 107 N.E. 758 (1914); State v. Globe Casket and Undertaking Co., 82 Wash. 124, 143 Pac. 878 (1914).

44a. A manufacturer attempting to do the same thing might be said to be violating the prohibition against "tie-in" sales provisions under $\$ 3$ of the Clayton Act. 38 Stat. 731 (1914), 15 U.S.C. $\$ 14$ (1946). Cf. Staniey Co. of America v. American Tel. \& Tel. Co., 4 F. Supp. 80 (D. Del. 1933); General Talking Picture Corp. v. American Tel. \& Tel. Co., 18 F. Supp. 650 (D. Del. 1937). He might likewise find himself guilty of an unfair method of competition in attempting to control the service business. Federal Trade Commission Act, 37 Stat. 719 (1914), as amended, 15 U.S.C. $\$ 45$ (a) (1946). 
(2) A manufacturer or dealer should not sell a service contract to repair products which he does not manufacture or sell.

(3) In the case of a manufacturer or dealer, the period of time for which the services are made available should be limited to that time in which the defects in workmanship normally appear. A renewal is as dangerous here as in a warranty against material defects.

(4) The contingencies should never be extended to include such fortuitous events as fire, theft or other external causes.

(5) Neither the manufacturer, dealer nor independent service man should assume the obligation to indemnify for consequential damage. ${ }^{45}$

Administrative Interpretations.-Since 1941, only one judicial decision has been rendered in this area. ${ }^{\mathbf{6}}$ This would seem to indicate that manufacturers, dealers and independent service men had abandoned their attempts to utilize this new selling device. But this is not the case. Oil burner dealers, automobile dealers, garage service men, elevator manufacturers, refrigerator and air conditioner manufacturers, a television manufacturer, ${ }^{47}$ television dealers and independent television service companies have been selling contracts to replace parts and furnish services. Whether these contracts bring the promisor within the insurance laws is currently troubling the various attorneys general and insurance commissioners. A survey of the forty-eight commissioners has been undertaken. Forty replies were received, including three rulings of attorneys general, eight commissioners' opinions previously made public, and twelve commissioners' opinions given solely in reply to the following two questions:

(1) Question: Is a manufacturer or dealer who enters into a contract with the public whereby he agrees for a stipulated time to maintain the product in workable order and to replace parts, engaging in the insurance business? Out of a total of 23 answers, two stated he was ${ }^{48}$ and 21 stated he was not. 49 Five of these 20 qualified their opinion by indicating that a renewal of such a contract would be considered insurance. ${ }^{50}$

45. See note 27 sipra.

46. Transportation Guarantee Co. v. Jellins, 29 Cal. 2d 242, 174 P.2d 625 (1946) (where the company agreed for a stated consideration to keep the owner's trucks in repair, furnish oil, gas, grease, etc., and to make good any damage due to collision, the agreement was held a service contract).

47. Radio Corporation of America.

48. Md. (Commissioner has requested an Attorney's General ruling), Fla. (also requested an Attorney's General ruling).

49. Cal., Colo., Conn. (Attorney's General ruling of July 7, 1950), Del., I11., Ind., Iowa (speech given by Samuel E. Orebaugh, Deputy Comm'r, at the Zone 4 Meeting of the National Association of Insurance Commissioners, May 8, 1952), Ky., La., Mass., Mich., Minn. (Attorney's General ruling of June 17, 1952), Mo., Nev., N.H. (press release, Retailing Daily, July 31, 1952), N.Y. [REP. ATT'Y GEN. 153 (N.Y. 1949)], Tenn. and W. Va. Three other states requested that their answers remain confidential.

50. I1l., Minn. (Attorney's General ruling of June 17, 1952), N.Y. [Rep. Atr'y Gen. 153 (N.Y. 1949)] and Tenn. One state requested that its answer remain confidential. 
(2) Question: Is an independent contractor, who for a consideration enters into a contract with the public whereby he agrees for a stipulated time to maintain the product in workable order and to replace parts, engaging in the insurance business? Out of 24 answers, 15 stated he was ${ }^{51}$ and nine stated he was not. ${ }^{2}$

Since the insurance statutes make regulation mandatory if the business is classified as insurance, the draftsman should consult the ruling of the attorney general of the state in which his client desires to do business. If there is no adverse ruling from this source, a consultation with the insurance commissioner may prove fruitful in terms of avoiding at the drafting stage possible problems.

\section{INviTATIONS To LIBERALISM}

Strict construction of the insurance statutes is commendable in any case where the main purpose of the contract is to spread risks, but not where the risk spreading device is incidental to the business in which the promisor is engaged. A manufacturer or dealer should be encouraged to stand behind the product which he sells. An attempt to do this in a more efficient manner than a warranty permits should not be stifled by a technical construction of the insurance laws. ${ }^{53}$ The "contingent incidental benefit" theory could relieve the harshness of the statutory regulations and better serve the public interest. Even if a court finds that the "guaranty" is technically an agreement to insure, it is not a necessary consequence that the insurance statutes should apply, ${ }^{54}$ since the legislative mandate is generally not clear,,$^{55}$ and the factors which motivated the passage of the statutes do not exist here..$^{56}$

If the manufacturer or dealer is not willing to assume the responsibility for maintaining his product in an efficient order, is there any reason why an

51. Cal., Conn. (Attorney's General ruling of July 7, 1950), Fla. (Attorney's General ruling of May 22, 1950 on a similar contract), Ill., Iowa (Speech given by Samuel E. Orebaugh, Deputy Comm'r, at the Zone 4 Meeting of the National Association of Ins. Commissioners, May 8, 1952), Ky., Mass., Md., Minn. (Attorney's General ruling of June 17, 1952), Mo., Neb., N.H. (press release, Retailing Daily, July 31, 1952), N.Y. [REP. Atr'y GeN. 153 (N.Y. 1949)], Tenn. and W. Va.

52. Colo., Del., Ind., La., Mich., and Nev. Three other states requested that their answers remain confidential.

53. Mr. Danial Creato, Vice-President of RCA Service Co., stated in an interview (Aug. 12, 1952) that, although there were evils caused by unethical or unskilled dealers, the consequences of subjecting the sellers of service and parts contracts to statutory insurance regulation would be to deprive the public of a valuable service.

54. Colaizzi v. Pennsylvania R.R., 208 N.Y. 275, 101 N.E. 859 (1913).

55. In a communication to the UNIVERSITY of PENNSYLVANIA LAW REviEw from Luke J. Kavanaugh, Colorado Commissioner of Insurance (Sept. 18, 1952), on file, Biddle Law Library, University of Pennsylvania Law School, the Commissioner stated: "I believe that it was not the intention of the Legislature that such petty merchandising problems should come under regulation by the Insurance Department of this State. It would be quite outside of our province to attempt to regulate or police the industry in these myriad matters."

56. Large sums of money are not held over a long period of time as service is generally required within a year; the nature of the contract limits the rise of evasive clauses; and there is no third party interest involved. 
independent service contractor should not be allowed to assume this duty by contracting to replace parts and render services upon the happening of specified contingencies, excluding external causes, without being regulated as an insurance company? Of course, it could be argued conceptually that this contract is not incidental to the service man's business; but there are public policy and sound business reasons militating against the result of regulation. Oil burners, electric diswashers, air conditioner units, automobiles, etc., are highly technical and need frequent attention. A regular inspection is often necessary for their safe operation. Their lack of mobility requires the additional cost of having the service man come to the product rather then the product going to the service man. Many of these articles have become so essential to the daily pattern of life that quick and ready service is demanded. By this type of contract the consumer can be assured of immediate, skilled service by personnel who will relieve him of the responsibility of maintaining the product at its full capacity and usefulness.

In addition to policy reasons, there are some legal hooks upon which a court may hang the desirable result. Unlike typical insurance, there is no third party interest involved and no large amount of money. A customer is buying something he is certain to utilize eventually; and the value of that product, like a tangible product, depends to a great extent upon the reliability of the seller or manufacturer. While it is possible for an independent contractor to become bankrupt owing services, this does not warrant the complete abolition of this type of service. ${ }^{57}$

\section{Practical Problems of the Insurance Commissioner}

Insurance commissioners are faced with a serious problem. If the commissioner or the attorney general decides that a contingent contract is insurance, the former with the help of the latter must enforce the insurance laws. The commissioner then is no longer solely involved in financial structures of insurance companies. He must apportion rates to the risk, not only for each class of products but for each individual make of product. An even more difficult administrative problem is the determination of the value of the services and parts in relation to the premiums paid. Because of these apparent administrative difficulties, three questions were posed to the insurance commissioners in regard to the television service contracts, with the following results: ${ }^{58}$

57. Mr. Danial Creato, Vice-President of the RCA Service Company, Inc., stated in an interview (Sept. 20, 1952), that insurance companies had not indicated any great desire to enter this field, probably because they felt that the cost of complying with the administrative details imposed by the insurance statute could price such a contract out of the market. In addition, their lack of know-how would increase the cost since they would have to sub-contract the work.

58. All non-confidential communications to the UNIversity of Pennsylvania LAw Revrew upon this subject are on file at the Biddle Law Library, University of Pennsylvania Law School. 
(1) Question: If the television service contracts should be held to be technically insurance, could your staff at its present size do an adequate job of policing the industry? Out of 34 answers, 14 thought their staff was adequate ${ }^{59}$ and 20 thought it was not adequate..$^{60}$

(2) Question: If the television service contracts should be held to be technically insurance, is there any public need for their regulation? Out of 27 answers, 14 thought there was a public need for regulation ${ }^{61}$ and 13 thought there was no public need for their regulation. ${ }^{62}$

(3) Question: If the television service contracts should be held to be technically insurance, would the administrative cost of incorporating as an insurance company and complying with the insurance statutes make the cost of such contracts so expensive that the selling of them would be impractical? Out of 27 answers, 18 thought that it would raise the cost so as to become prohibitive ${ }^{83}$ and nine thought it would not. ${ }^{64}$

\section{Proposed Solutions}

The following solutions are offered to the problems raised by riskshifting contracts which are used as sales devices or used by an independent contractor in order to increase his service business. The specific problem at which they are aimed is television service contracts.

(1) Although there is danger of the public being "gyped" 65 by the sellers of television service contracts, the same problem exists in the purchase of any merchandise. Since the customer-promisee is buying something which he is certain to need, the purchase of a service contract is analogous to the purchase of any tangible product. ${ }^{68}$ In both cases the purchaser is in the same position if the service rendered, by the product or by

59. Cal., Conn., Ill., Iowa, Ky., Md., Mass., Minn., Neb., N.H., N.Y., Okla., Ore. and $\mathrm{W}$. Va.

60. Ala., Ark., Colo., Ind., La., Mich., Miss., Mo., Nev., N.D., R.I., S.D., Vt., and Wis. Six states requested that their answers remain confidential.

61. Ark., Conn. (when a manufacturer does not sell them), Ill., Iowa, Ky., Md., Mass., Minn., Miss., N.H., N.Y., Ore. and W. Va. One state requested that its answer remain confidential.

62. Colo., Ind., Mich., Neb., Nev., S.D., Vt. and Wis. Five states requested that their answers remain confidential.

63. Ark., Colo., Conn., Ind., La., Md., Neb., Nev., N.H., N.Y., N.D., R.I., and $\mathrm{Vt}$. Five states requested that their answers remain confidential.

64. Iowa, Kan., Ky., Mass., Minn., Miss., S.D. and W. Va. One state requested that its answer remain confidential.

65. See How TV Racketeers Gyp You, 60 READER's Drgest 103 (June, 1952).

66. It is not certain that one will have a fire but it is certain one will require service and replacement of parts, since only a limited number of useful hours can be built into any mechanical or electronic part. In addition, most television contracts provide for other services which the consumer can utilize, such as inspection and instruction in operation. 
the service man, is not satisfactory. If the seller of such a contract becomes insolvent, the service which the promisee has purchased will never be received; likewise, in the purchase of a product with a warranty, if the seller becomes insolvent, the customer will never receive the protection which he has paid for in the initial sale price. The cost of the warranty is not so great as the $\$ 5$ to $\$ 75$ one-year television service contract, but does the difference in this amount of money warrant the stringent regulation imposed by the insurance statutes? The answer seems clearly no. A better solution would be to allow the customer to rely upon his own business acumen with the aid of the Better Business Bureau.

(2) Since the insurance commissioners, under the insurance statutes, have no discretion in deciding what must be regulated, or, to a large extent, the degree of regulation, the statutes should be amended to grant discretion to the commissioner in these borderline cases.

(3) The various trade associations, such as the Radio-Television Manufacturers' Association, could assume responsibility for the policing of the industry.

(4) To stimulate more responsibility on the part of the seller of such a contract, he should be required to post a bond and secure a license. ${ }^{67}$

(5) As a last alternative, an established insurance company might write these contracts, ${ }^{68}$ but the statutes could allow the rates, method of selling, degree of coverage, time of coverage, etc., to be decided solely by the seller of the contract and the insurance company.

Any of the above solutions would be better then requiring a certain minimum capital in order to offer this type of contract, since that would be futile unless rates were controlled. To require a large capital reserve at all times would make the offering of this type of contract impractical for all but a few large manufacturing firms.

The issue resolves itself into whether the insurance statutes should stand in the way of businessmen's attempts to give the American public what they are demanding. The common sense answer seems to be no. If regulation is needed it must be done with a lighter hand then the insurance laws permit, or the public demand will go unsatisfied.

67. The licensing requirement was recently advocated by a Philadelphia City councilman. See The Philadelphia Evening Bulletin Nov. 18, 1952, p. 22, col. 2.

68. After difficulty in getting an insurance company to enter this field, one service company is now operating under an arrangement in New York, whereby the insurance company is the promisor, the service company is the promisee, and the policyholder is the third-party beneficiary. Because of the ruling of the Attorney General, this arrangement apparently would not be necessary for first year contracts of the manufacturer or his distributor or dealer. 